\title{
MUDANÇAS ATUAIS NA SOCIEDADE BRASILEIRA E O SISTEMA NACIONAL DE EDUCAÇÃO: QUALIDADE DA EDUCAÇÃO PÚBLICA COMO DIREITO HUMANO
}

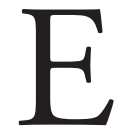

mbora o slogan eleitoral do recém-iniciado segundo mandato presidencial tenha sido "Brasil, pátria educadora", indicativo da verbalizada intenção governamental de elevar a educação ao patamar de "prioridade das prioridades", os rumos econômicos assumidos pelo novo governo comprometem o futuro da educação brasileira. A título de ilustração, cabe lembrar que, segundo estudo do IPEA (2011), a cada aumento de 1 ponto percentual na taxa de juros o governo gasta o equivalente a $0,6 \%$ do PIB, o que corresponde a quase três vezes a complementação da União ao Fundeb ${ }^{1}$. Em outras palavras, uma redução de 1,5 pontos percentuais da Taxa Selic já viabilizaria o CAQi (Custo Aluno Qualidade inicial), o mesmo CAQi que, não fora a mobilização da sociedade civil, não estaria incorporado ao atual Plano Nacional da Educação (PNE). Sem essa mesma mobilização, não constaria também no Plano o percentual de $10 \%$ do PIB para a educação até 2024. As também recentes mudanças em programas de financiamento educacional, bem como o atraso na alocação de recursos para programas anunciados em campanha eleitoral como prioritários pelo novo governo, denotam um cenário confuso e preocupante para o futuro da educação brasileira.

Os desafios postos atualmente e os que nos esperam nestes próximos quatro anos, vêm sendo enfrentados pelo Governo Federal com medidas conflitantes e flagrantemente incompatíveis com as propostas eleitorais. Assim, por exemplo, inclui-se no PNE a utilizaçáo de indicadores de qualidade com base na Avaliação Institucional e, ao mesmo tempo, fixa-se uma meta de atingimento do Ideb e até do Pisa, exame idealizado e elaborado para atender as demandas da OCDE. Do mesmo modo, incluem-se os $10 \%$ do PIB para a educação, mas facilita-se enormemente a destinação de recursos públicos ao setor privado. E o que é pior, sem buscar - até agora - estabelecer diálogo e possível canal de negociação com os sujeitos sociais coletivos. A despeito dos posicionamentos assumidos após longas e renhidas discussóes por entidades integrantes do Fórum Nacional da Educação, nem mesmo a Conferência Nacional da Educação (Conae), realizada 
não em fevereiro como previsto, mas somente em novembro de 2014, reunindo delegados representantes de todos os níveis, etapas e modalidades de ensino, organizada para propiciar o debate entre educadores, foi concretizada em tempo hábil para que as suas demandas educacionais pudessem ser incorporadas ao Plano Nacional da Educação, inicialmente previsto para 2010-2020, porém só aprovado em junho de 2014 (com imenso atraso!) pelo Congresso Nacional. Mais do que mediar as disputas de diferentes concepçóes no campo da educação, definindo finalmente uma posição, medidas têm sido tomadas em zona amorfa e permeada de ambiguidades.

As declaraçôes do novo Ministro da Educação apontam para a "reformulação radical do ensino médio" centrada na "revisão curricular" ${ }^{2}$, no prazo de dois anos. Seguindo as propostas do polêmico Projeto 6.840/2013, em tramitação na Câmara Federal, e aparentemente sem acompanhar os últimos acordos efetuados entre o seu relator e as entidades estudantis e as do Movimento Nacional em Defesa do Ensino Médio, formalizados no Substitutivo ao PL (aprovado na última reuniấo da Comissão Especial, em dezembro, e que deverá ser votado em 2015 pelo plenário da Câmara), Cid Gomes retoma as já desgastadas propostas empresariais de organizar os currículos a partir do que designa como "grandes áreas" de conhecimento, caminho elegido para torná-los "mais palatáveis" à juventude. No entanto, contrariando as Diretrizes Curriculares Nacionais do Ensino Médio, definidas socialmente e aprovadas pelo Conselho Nacional de Educação (CNE), a organização curricular pretendida fragmenta e hierarquiza os diferentes saberes em vez de procurar integra-los. O Ministro prometeu, ao menos, que tais mudanças seriam precedidas de ampla discussão, por meio de "[...] um debate aprofundado com diferentes atores sociais [...]".

A revisão curricular deverá ocorrer simultaneamente a outro debate previsto no PNE que também envolverá grande disputa política: a definição das bases nacionais curriculares comuns no ensino fundamental e médio, ou seja, a definição dos conteúdos mínimos a serem estudados nas escolas do país.

É neste quadro de grande complexidade que o Plano Nacional da Educação, apresentado ao Congresso Nacional por Mensagem Presidencial em 2010, sancionado e publicado no DOU em 25/06/2014, coloca para todos nós, comprometidos com a educação pública como direito, democrática, de qualidade referida socialmente e laica, o desafio da institucionalização em Lei do Sistema Nacional da Educação (SNE) nos próximos dois anos.

É importante que fiquem visíveis os interesses de grupos e forças políticas e econômicas antagônicas que disputam o campo educacional no Brasil. Tais antagonismos manifestam-se tanto no entendimento dado à concepção de educação presente no artigo 205 da Constituição Federal e nos princípios dele decorrentes, artigo 206, quanto no texto do PNE já aprovado. 
Correndo o risco de sermos demasiadamente sintéticos, assinala-se que se opóem nesses posicionamentos, de um lado, a concepção mercantilista da educação respaldada na teoria do Capital Humano e, de outro, a concepção do desenvolvimento humano, do direito à cidadania e da qualificação para o trabalho.

Tendo em vista estas divergências e, ao mesmo tempo, considerando o fato de que elas não se opóem, mas se hibridizam no PNE, o V Seminário da Educação Brasileira (SEB), a ser realizado em junho de 2015, se propóe analisar e debater tanto as posições antagônicas quanto a concertação entre elas, que são o substrato do Plano.

A presente proposta editorial que, inovadoramente, antecipa a publicação dos textos que serão debatidos no V SEB, problematiza a constituição do SNE no contexto de mudanças estruturais e sociais em curso na desigual sociedade brasileira contemporânea, considerando:

a) o campo do trabalho, com implicaçôes socioespaciais e econômicas: o urbano (reorganização das cidades e territórios: metrópoles, periferias); e o rural (agroindústria, cooperativismo e assentamentos, os quais expressam mudanças no campo que se associam com o urbano em algumas situaçōes);

b) a organização atual do Estado, que envolve novas relaçōes público/ privado e incide sobre a concepçáo do direito à educaçáo pública de qualidade socialmente referenciada, substituindo-a por outra que, sustentada em uma racionalidade pragmática, instrumental, restringe o direito à educação de qualidade ao que pode ser mensurado.

Espera-se que o V SEB e a interlocução propiciada a seus participantes pela publicação antecipada de textos, possa contribuir como mais um instrumento de reflexão e organização dos educadores e suas instâncias deliberativas, no acompanhamento efetivo das metas do PNE e dos Planos Estaduais e Municipais de Educação, com ampla participação dos vários setores sociais, e, dessa forma, para a construção do Sistema Nacional de Educação e a democratização da escola pública de qualidade social em nosso país.

\section{Notas}

1. INSTITUTO DE PESQUISA ECONÔMICA APLICADA. Financiamento da Educação: Necessidades e Possibilidades. Comunicado IPEA, n. 124. Brasília: IPEA, 14 de dezembro de 2011.

2. MUDANÇAS NO ENSINO MÉDIO. NOVO MODELO CONTRA VELHO PROBLEMA. Rio de Janeiro: O Globo, 03/01/2015, p. 22, versão impressa. 